\title{
Quality Information Analysis of DHF Epidemiological Surveillance System at Trenggalek District Health Office
}

\author{
Syifa'ul Lailiyah ${ }^{1}$, Chatarina Umbul Wahyuni ${ }^{2}$, Atik Choirul Hidajah ${ }^{3}$ \\ ${ }^{1}$ Public Health Study Program of Airlangga University-PDD Banyuwangi, Indonesia \\ ${ }^{1}$ lailiyahsyifaulegmail.com \\ ${ }^{2,3}$ Department Of Epidemiology, Public Health Faculty of Airlangga University, Indonesia \\ ${ }^{2}$ Chatrin03@yahoo.com \\ 3atik.ch0211@gmail.com
}

\begin{abstract}
The highest Incidence Rate of DHF at East Java Province in 2008 was Trenggalek District $(123.69 / 100.000$ population). During 2008, DHF has infected all areas of public health services center, tendency of increase in the number of endemic villages and sporadic from year to year and decrease in the number of villages that were free / potential, and an outbreak started from $1^{\text {st }}$ week to $22^{\text {nd }}$. In order to control DHF, required qualified information of epidemiological surveillance system. The research objective was to analyze DHF epidemiological surveillance system that could provide qualified information. This research was a descriptive research. The research was conducted in the DHF P2 Program, P2 Section, P3-PL Division of Trenggalek District Health Office. Informants were the Head of the P3-PL, Head of P2 Section, DHF P2 Program Manager, and DHF surveillance staff. Types of data were primary and secondary data. Data analysis by descriptive analysis. The result of input analysis were reporting documents (W2, DP-DBD, KDBD) from public health services center were not available, reporting documents (K-DBD) to provincial health office that was not available, the used indicators of DHF epidemiological surveillance system was uncomplete. The process analysis were collected data was uncomplete, reports from public health services center was often too late and cumulative collected, lack of KD-RS reports attendance, lack of data accuracy, lack of sharability, ineffective and inefficient of DHF epidemiological surveillance data compilation. The output analysis were lack of information accuracy and uncompleteness of information on districts's DHF surveillance performance indicators.
\end{abstract}

Keywords — Include DHF, system analysis, epidemiological surveillance

\section{INTRODUCTION}

DHF was a disease of public health problem and endemic throughout the City/Regency in Indonesia [1]. Based on the Law of the Republic of Indonesia Number 4 of 1984 on outbreaks of infectious diseases, DHF was also one type of disease that could cause an outbreak [1]-[5]. The highest Incidence Rate of DHF at East Java Province in
2008 was Trenggalek District (123.69/100.000 population) [6]. During 2008, DHF has infected all areas of public health services center (22 units), tendency of increase in the number of endemic villages and sporadic from year to year and decrease in the number of villages that were free / potential, and an outbreak started from $1^{\text {st }}$ week to $22^{\text {nd }}$ week with the number of cases were 714 cases and 4 deaths in Trenggalek District [7].

There were differences number of Trenggalek's DHF cases: a) Differences in the number of cases among the manual recapitulation, annual reports of P2 Trenggalek District Health Office, and the list of DHF cases (Trenggalek) in East Java Provincial Health Office, b) There were two sum of cases in the manual recapitulation. Based on the problem identification would required an analysis of the quality information of DHF epidemiological surveillance system. Provision of data and quality epidemiological information used as a basis for decision making in the planning, implementation, monitoring, evaluation of health programs and increase awareness of and response to outbreaks quickly and accurately. The objective of the research was to analyse DHF epidemiological surveillance system that could provide the quality information for Trenggalek District Health Office.

\section{METHODS}

This research was a descriptive research [8], [9]. The research was conducted in the DHF P2 Program, P2 Section, P3-PL Division of Trenggalek District Health Office. Informants were the Head of 
the P3-PL, Head of P2 Section, DHF P2 Program Manager, and DHF surveillance staff. Types of data were primary and secondary data. Primary data was obtained by structured interview, while the secondary data was obtained by the study of documents. Data analysis by descriptive analysis.

\section{RESULTS}

Analysis of surveillance systems consist of component input, process, and output as follows [4], [10]-[14].

\section{A. Input Analysis}

\section{1) Man}

Characteristics of DHF epidemiological surveillance system officer shown in the Table 1 below.

TABLE I

CHARACTERISTICS OF DHF EPIDEMIOLOGICAL SURVEILLANCE SYSTEM OFFICER

\begin{tabular}{|l|l|l|l|l|}
\hline No. & \multicolumn{1}{|c|}{ Officer } & Education & $\begin{array}{l}\text { Surveillance } \\
\text { Training } \\
\text { Frequency }\end{array}$ & $\begin{array}{l}\text { Ability to } \\
\text { Operate } \\
\text { Computer }\end{array}$ \\
\hline 1 & $\begin{array}{l}\text { DHF program } \\
\text { staff }\end{array}$ & $\begin{array}{l}\text { Diploma } \\
\text { (AKL) }\end{array}$ & None & Capable \\
\hline 2 & $\begin{array}{l}\text { W2 reporting } \\
\text { staff }\end{array}$ & $\begin{array}{l}\text { Senior High } \\
\text { School } \\
\text { (SPPH) }\end{array}$ & None & Capable \\
\hline 3 & $\begin{array}{l}\text { STP reporting } \\
\text { staff }\end{array}$ & $\begin{array}{l}\text { Bachelor } \\
\text { (SKM) }\end{array}$ & None & Capable \\
\hline 4 & $\begin{array}{l}\text { STP KLB and } \\
\text { W1 reporting } \\
\text { staff }\end{array}$ & $\begin{array}{l}\text { Diploma } \\
\text { (AKL) }\end{array}$ & None & Capable \\
\hline
\end{tabular}

\section{2) Money}

Source of funding DHF epidemiologic surveillance in 2010 only from APBD. Based on the officer information, funding for DHF epidemiologic surveillance was still not enough.

\section{3) Material}

Sources of data in the system of epidemiological surveillance of dengue were 22 public health service centers (Trenggalek, Rejowinangun, Durenan, Baruharjo, Pogalan, Ngulan Kulon, Tugu, Pucanganak, Gandusari, Karanganyar, Watulimo, Slawe, Kampak, Suruh, Karangan, Pule, Bendungan, Dongko, Pandean, Panggul, Bodag, and Munjungan); hospitals (District Public Hospital Dr. Soedomo, Budi Asih Hospital, and Mardi
Mulya Hospital); and other hospitals outside the Trenggalek District.

Report formats, data, and indicators used in the DHF epidemiologic surveillance shown in the Table 2 below.

TABLE II

REPORT FORMATS, DATA, AND INDICATORS USED IN THE DHF EPIDEMIOLOGIC SURVEILLANCE SYSTEM

\begin{tabular}{|c|c|c|}
\hline Report Formats & Data & Indicators \\
\hline $\begin{array}{l}\text { Public health } \\
\text { service center } \\
\text { formats: KD-RS } \\
\text { DBD, W2 public } \\
\text { health service } \\
\text { center, W1, STP, } \\
\text { cross notification, } \\
\text { PE, abatisasi, } \\
\text { fogging and ULV, } \\
\text { PSN, PJB, } \\
\text { population } \\
\text { projection, and } \\
\text { village by Jumantik. } \\
\text { Districts health } \\
\text { office formats: W2 } \\
\text { district, dengue } \\
\text { virus infection, and } \\
\text { disease controlling } \\
\text { program. }\end{array}$ & $\begin{array}{l}\text { DBD cases, } \\
\text { DBD death } \\
\text { cases, } \\
\text { diagnosis } \\
\text { clasification, } \\
\text { laboratory } \\
\text { results, } \\
\text { number of } \\
\text { population, } \\
\text { ABJ, PE, } \\
\text { abatisasi, } \\
\text { PSN, PJB, } \\
\text { number of } \\
\text { trained } \\
\text { Jumantik, and } \\
\text { number of } \\
\text { villages with } \\
\text { Jumantik. }\end{array}$ & $\begin{array}{l}\text { Completeness of W2 } \\
\text { reports }(80 \%) \text {, } \\
\text { timeliness of W2 } \\
\text { reports }(80 \%) \text {, } \\
\text { availability of } \\
\text { endemicity and the } \\
\text { distribution of cases by } \\
\text { district, } \\
\text { could determined the } \\
\text { time of the transmission } \\
\text { season in the district, } \\
\text { could determined the } \\
\text { trend of DHF in the } \\
\text { district, and } \\
\text { the availability of } \\
\text { demographic data, IR } \\
(<20 / 100.000 \\
\text { population), CFR }(<1 \%) \text {, } \\
\text { and ABJ }(\geq 95 \%)\end{array}$ \\
\hline
\end{tabular}

\section{4) Machine}

Type of DHF epidemiological surveillance system equipment shown in the Table 3 below.

TABLE III

TyPE OF DHF EPIDEMIOLOGICAL SURVEILLANCE SySTEM EQUIPMENT

\begin{tabular}{|l|l|l|l|}
\hline No. & \multicolumn{1}{|c|}{ Type } & Amount & \multicolumn{1}{c|}{ Condition } \\
\hline 1 & Computer set & 3 & Good \\
\hline 2 & Printer & 2 & Good \\
\hline 3 & Fax machine & 1 & Good \\
\hline 4 & Telephone & 1 & Good \\
\hline 5 & Fogging vehicle & 1 & Good \\
\hline 6 & Calculator & 1 & Good \\
\hline 7 & Epidemiology calendar & 2 & Good \\
\hline 8 & Software & 1 & Office aplication \\
\hline
\end{tabular}

\section{5) Method}

Implementation of DHF epidemiological surveillance system followed the guidelines of DHF program in Indonesia version 2005 and 2007. 


\section{B. Process Analysis}

Data collection of DHF epidemiological surveillance system was passive surveillance system [11], [12]). Notice the suspect/cases DHF in the working area of public health service centers in addition to the suspect/cases DHF were treated in public health service centers, it also received a notice from the district health office (if hospital cured for the suspect/cases DHF who lived in the working area of public health service centers) and receive reports from TEDES (Village Epidemiological Team).

The report and frequency of reporting from hospitals and public health service centers to district health office were shown in the Table 4 below.

TABLE IV

FREQUENCY OF DHF EPIDEMIOLOGICAL SURVEILLANCE SYSTEM REPORTING

\begin{tabular}{|c|c|c|c|c|}
\hline No. & Unit & Report & $\begin{array}{c}\text { Frequency of } \\
\text { Reporting }\end{array}$ & $\begin{array}{c}\text { Limit of } \\
\text { Reporting }\end{array}$ \\
\hline \multirow[t]{2}{*}{1} & \multirow[t]{2}{*}{ Hospital } & $\begin{array}{l}\text { KD-RS } \\
\text { DBD }\end{array}$ & Daily & $\begin{array}{l}24 \mathrm{~h} \text { from first } \\
\text { diagnosted }\end{array}$ \\
\hline & & STP & Monthly & Date $10^{\text {th }}$ \\
\hline \multirow[t]{7}{*}{2} & \multirow{7}{*}{$\begin{array}{l}\text { Public } \\
\text { health } \\
\text { service } \\
\text { center }\end{array}$} & $\begin{array}{l}\text { KD-RS } \\
\text { DBD }\end{array}$ & $\begin{array}{l}\text { Daily } \\
\text { Monthly }\end{array}$ & $\begin{array}{l}\text { Monday- } \\
\text { Wednesday }\end{array}$ \\
\hline & & W2 & Weekly & \\
\hline & & STP & Monthly & Date $5^{\text {th }}$ \\
\hline & & PE & Soon & $24 \mathrm{~h}$ \\
\hline & & Controling & Soon & $24 \mathrm{~h}$ \\
\hline & & PJB & Quarterly & $1^{\text {st }}$ week \\
\hline & & Jumantik & Yearly & Not specified \\
\hline
\end{tabular}

Obstacles that often occurs in the data collection was the delay in the reporting from the public health service center, a report sent to one or two months, and the form of reporting formats (KD-RS and abatisasi DBD) was not uniform caused difficulties in data processing.

Data compilation used a master table and then typed into the computer. Updating the data on the master table by adding new data and deletion of old data. Frequency compilation were daily, weekly, monthly, quarterly, and yearly. Data compilation by category: epidemiology variable (man, place, and time); number of PE (Epidemiology Investigation), PSN (Eradication of Mosqouite Breeding Place), PJB (Periodic Larvae Monitoring), abatisasi, fogging and ULV (Ultra Low Volume), ABJ (Free Numbers of Larvae), trained jumantik (larva supervisor), village with jumantik by the district. Obstacles in the data compilation was used of computers in turn.

Data analysis used the help of a calculator and a computer with office application. Forms of data analysis was to calculate the variable and connect the two variables. Data was presented in narrative form, tables, and graphs. Interpretation of the data showed the DHF trends and determined the DHF transmission season.

\section{Output Analysis}

The information generated by the DHF epidemiological surveillance system in Trenggalek District Health Office were: completeness of W2 reports (92\%), timeliness of W2 reports (46\%), endemicity, the distribution of cases by district, IR of DHF (92.69/100.000 population), CFR of DHF (0.75\%), ABJ (90.79\%), number of PE, PSN, PJB, abatisasi, fogging and ULV, trained jumantik, village with jumantik, DHF trends and determined the DHF transmission season. Information that has been generated in the system then disseminated to head of P2 section, head of P3-PL division, head of Trenggalek District Health Office, DHF program of P2 section provincial health office, surveillance program P3-PMK section provincial health office, and public health service center. Reporting lines in the DHF epidemiological surveillance system presented in the Fig. 1 below.

Based on the description of component input, process and output, then the flow of data within the system could be described in the Data Flow Diagrams (DFD) Fig. 2 and Fig. 3 below. 


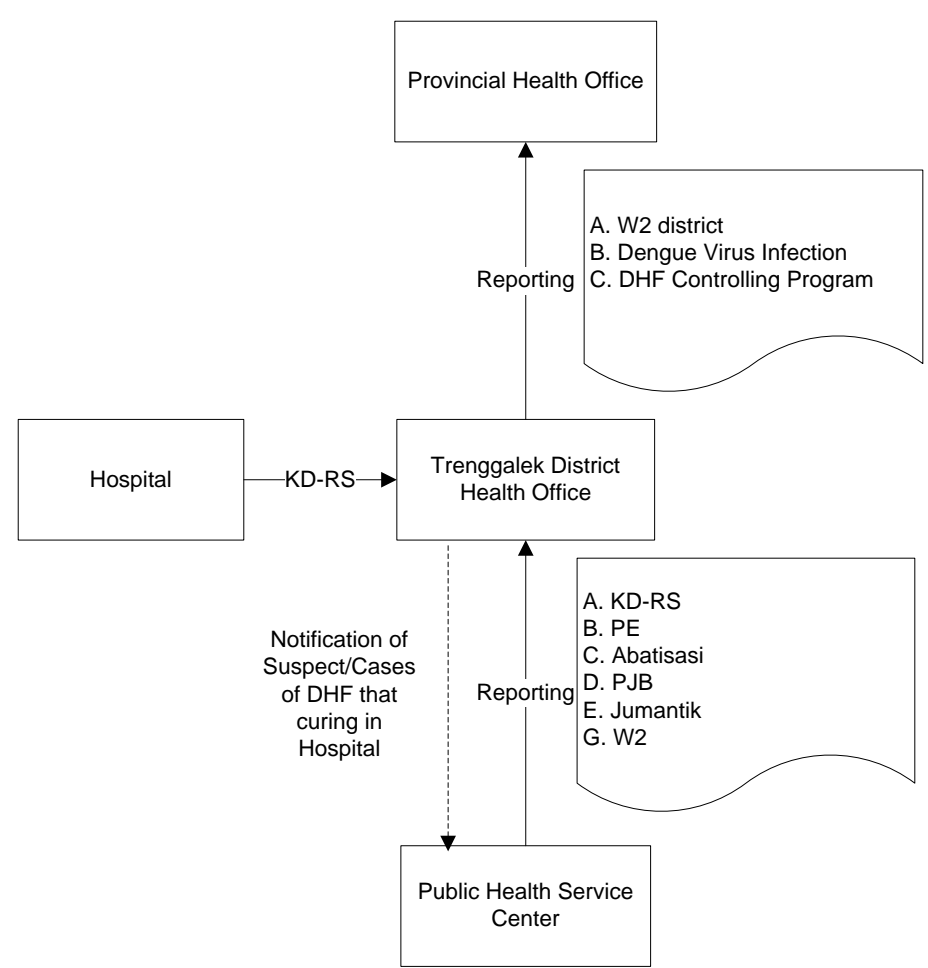

Fig. 1 Flow diagram of DHF epidemiological surveillance data reporting

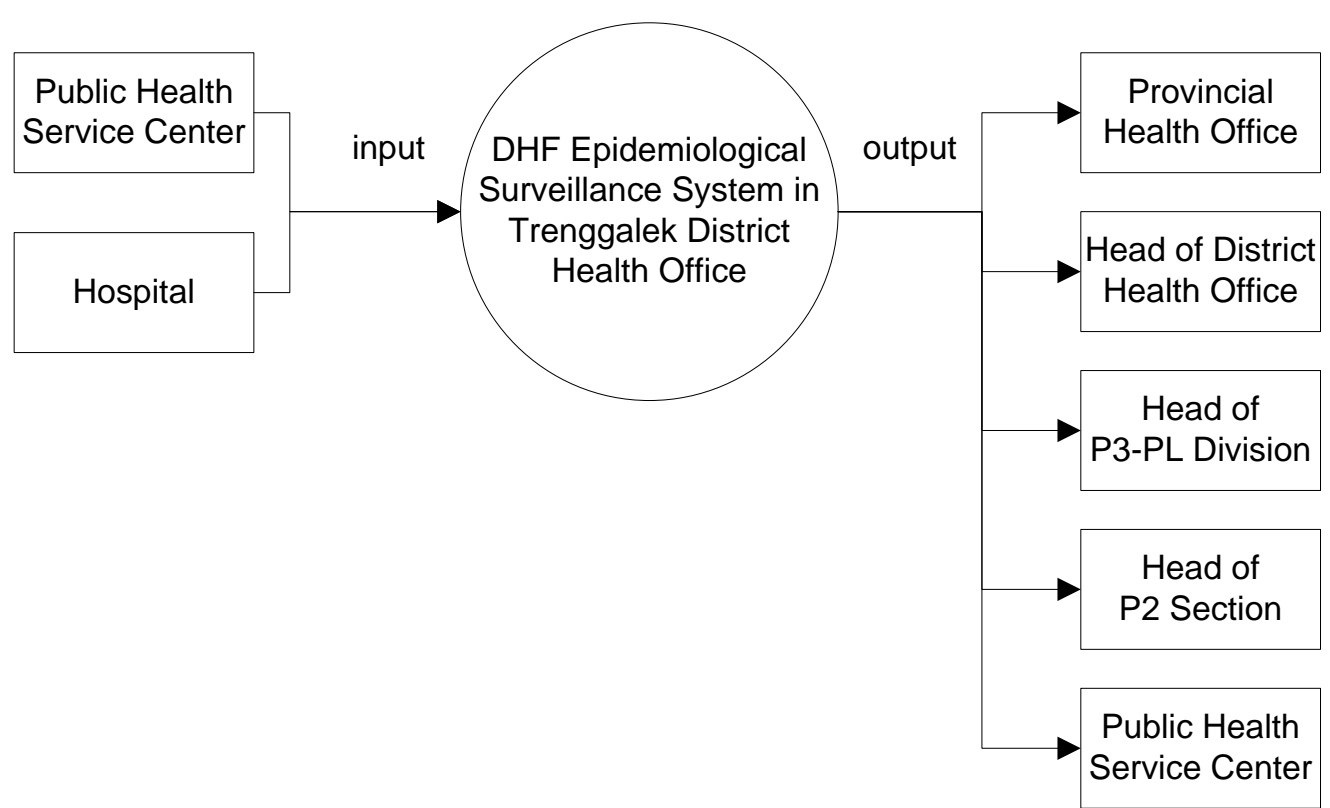

Fig. 2 Context diagram of DHF epidemiological surveillance system 


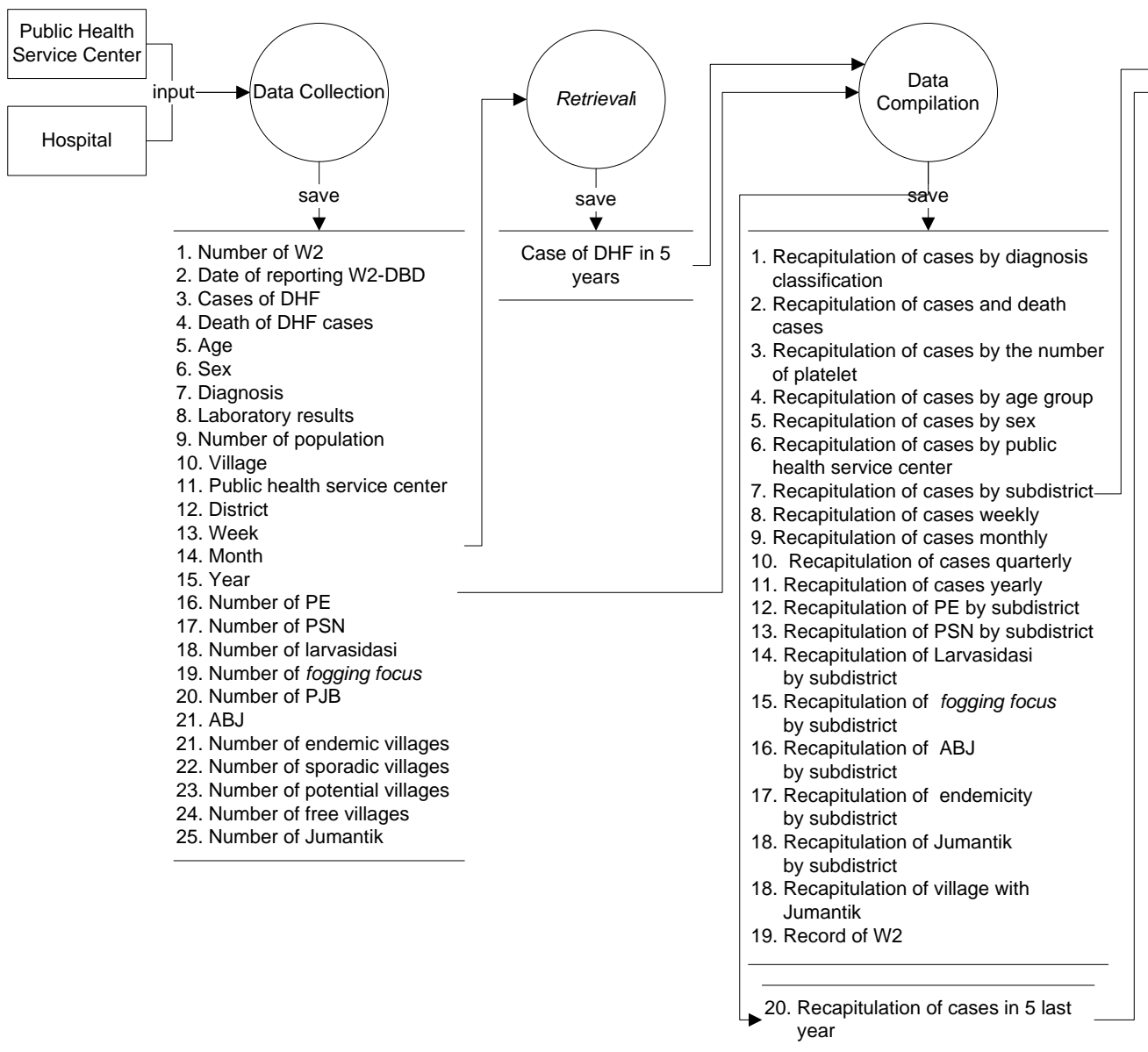

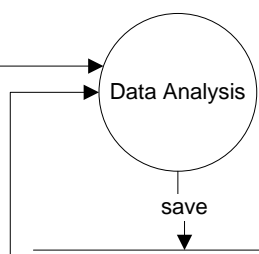

1. Completeness of $W$

2. Timeliness of W2

3. Endemicity of village

4. Cases distribution by:

a. Number of DHF cases

b. Number of DHF death cases

c. Proportion of cases by the number of platelet

d. Proportion of cases by sex

e. Proportion of cases by age group

f. Number of DHF cases weekly

g. Number of DHF cases monthly

h. Number of DHF cases quarterly

i. Number of DHF cases yearly

5. Average of DHF cases by year

6. IR of DHF

7. $\mathrm{CFR}$ of $\mathrm{DHF}$

8. ABJ

9. Number of $P E$

10. Number of PSN

11. Number of larvasidasi

12. Number of fogging focus

13. Number of PJB

14. Number of Jumantik

15. Number of village with Jumantik

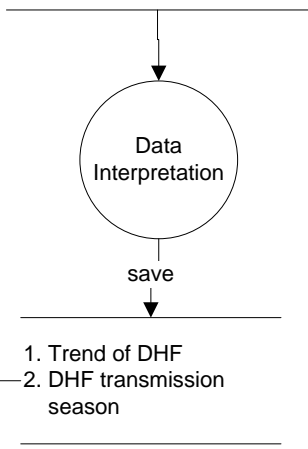

DHF transmission

\begin{tabular}{|c|l|}
\hline Provincial \\
Health Office
\end{tabular}

1. Completeness of W2

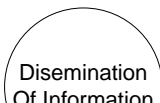
Of Information save

Fig. 3 Level 0 diagram of DHF epidemiological surveillance system 
Based on description of all component analysis was identified the DHF epidemiological surveillance system problems in The Trenggalek District Health Office. It shown in Table 5.

TABLE V

DHF EPIDEMIOLOGICAL SURVEILLANCE SYSTEM PROBLEMS

\begin{tabular}{|l|l|l|}
\hline No. & Component & \multicolumn{1}{c|}{ Problems } \\
\hline 1 & Input & $\begin{array}{l}\text { a. Reporting documents from public health } \\
\text { service centers to health districts office } \\
\text { that were not available were reports } \\
\text { W2-DBD, DP-DBD, K-DBD. } \\
\text { b. Reporting documents from district } \\
\text { health office to the provincial health } \\
\text { office that were not available were K- } \\
\text { DBD. } \\
\text { c. Indicators of DHF epidemiological } \\
\text { surveillance system used was less } \\
\text { complete than the standard indicators of } \\
\text { DHF epidemiological surveillance } \\
\text { system. }\end{array}$ \\
\hline 2 & $\begin{array}{l}\text { a. The data collected was less complete } \\
\text { than the standard data collection of DHF } \\
\text { epidemiological surveillance system. } \\
\text { b. Reporting from public health service } \\
\text { centers is often too late and collected } \\
\text { cumulative. } \\
\text { c. The lack of attendance KD-RS reports. } \\
\text { d.Data compilation was less effective and } \\
\text { efficient. }\end{array}$ \\
\hline 3 & Output & $\begin{array}{l}\text { a. The informations were incomplete when } \\
\text { compared to the standard indicators of } \\
\text { DHF epidemiological surveillance } \\
\text { systems. That were: completeness of } \\
\text { public health service centers reporting } \\
\text { (W2-DBD, DP-DBD, and K-DBD); the } \\
\text { timeliness of public health service } \\
\text { centers reporting (W2-DBD, DP-DBD, } \\
\text { and K-DBD); and report of the KD-RS } \\
\text { was received no more than 24 hours } \\
\text { since the first diagnosis. } \\
\text { b. The indicators that have not reached the } \\
\text { target were: the timeliness of reports } \\
\text { W2 amounted to 46\%; IR of DHF } \\
\text { amounted to 92.69/100,000 population; } \\
\text { ABJ amounted to 90.799\%. } \\
\text { c. There was no feedback to the hospital as } \\
\text { a data provider. }\end{array}$ \\
\hline
\end{tabular}

\section{CONCLUSIONS}

The result of input analysis were reporting documents (W2, DP-DBD, K-DBD) from public health services center were not available, reporting documents (K-DBD) to provincial health office that was not available, the used indicators of DHF epidemiological surveillance system was uncomplete. The process analysis were collected data was uncomplete, reports from public health services center was often too late and cumulative collected, lack of KD-RS reports attendance, lack of data accuracy, lack of sharability, ineffective and inefficient of DHF epidemiological surveillance data compilation. The output analysis were lack of information accuracy and uncompleteness of information on districts's DHF surveillance performance indicators.

\section{REFERENCES}

[1] Departemen Kesehatan RI, Rencana Pembangunan Jangka PanjangBidang Kesehatan 2005-2025, Jakarta: Departemen Kesehatan RI, 2009.

[2] Kemenkes RI, Rencana Strategis Kementerian Kesehatan Tahun 2010 2014: Keputusan Menteri Kesehatan Republik Indonesia Nomor: HK.03.01/160/I/2010, Jakarta: Kemenkes RI, 2010.

[3] WHO, Dengue: Guidelines for Diagnosis, Treatment, Prevention, and Control, New Edition 2009, France: WHO, 2009.

[4] Ditjen PP \& PL Depkes RI, Modul Pelatihan Bagi Pengelola Program Pengendalian Penyakit Demam Berdarah Dengue Di Indonesia: Materi 1 Peraturan Perundang-undangan Dan Kebijakan Nasional Program Pengendalian Penyakit, Jakarta: Direktorat Jenderal Pengendalian Penyakit dan Penyehatan Lingkungan Departemen Kesehatan RI, 2007.

[5] Soegijanto. Soegeng, Hariadi. Soedjoko, Demam Berdarah Dengue Edisi 2: Pola Distribusi Serotipe Virus Dengue Pada Beberapa Daerah Endemik di Jawa Timur dengan Kondisi Geografis Berbeda, Surabaya: Airlangga University Press, 2006.

[6] Program P2 DBD Dinkes Propinsi Jatim, Daftar Penderita dan Kematian DBD Propinsi Jawa Timur Tahun 2004-2008, Surabaya: 2009

[7] P2 Dinkes Kabupaten Trenggalek, Laporan Tahunan Bidang Pemberantasan Penyakit (P2) Dinas Kesehatan Kabupaten Trenggalek Tahun 2008, Trenggalek: Bidang Pemberantasan Penyakit (P2) Dinas Kesehatan Kabupaten Trenggalek, 2009.

[8] Widi. Restu Kartiko, Asas Metodologi Penelitian: Sebuah Pengenalan dan Penuntun Langkah Demi Langkah Pelaksanaan Penelitian, Yogyakarta: Graha Ilmu, 2010.

[9] Notoatmodjo. Soekidjo, Metode Penelitian Kesehatan, Jakarta: PT. Rineka Cipta, 2002.

[10] Groseclose. Samuel L, Sullivan. Kevin M, Gibbs. Norma P, Knowless, Carol M, Principles and Practice of Public Health Surveillance Second Edition. Chapter 5: Management of the Surveillance and Quality Control of Data. New York: Oxford University Press, 2000.

[11] Janes. Gail R, Hutwagner. Lori, JR, Williard Cates, Stroup. Donna F, Williamson. G. David, Principles and Practice of Public Health Surveillance Second Edition, Chapter 6: Descriptif Epidemiologi: Analyzing and Interpretating Surveillance Data., New York: Oxford University Press, 2000.

[12] Klaucke. Douglas N, Public Health Surveillance, Chapter 2: Evaluating Public Health Surveillance, New York: John Wiley \& Sons Inc, 1992.

[13] Thacker. Stephen B, Principles and Practice of Public Health Surveillance Second Edition, Chapter 1: Historical Development, New York: Oxford University Press, 2000.

[14] Arias. Kathleen Meehan, Harkavy, Lorraine Messinger, Quick Reference To Outbreak Investigation and Control in Health Care Facilities, Chapter 2: Routine Surveillance Programs for Health Care Facilities, Maryland: Aspen Publishers, Inc, 2000. 